\title{
McCarran-Ferguson Act Immunity from the Truth in Lending Act and Title VII
}

The McCarran-Ferguson Act" immunizes the "business of insurance" from federal laws that would "invalidate, impair, or supersede" state regulation. This immunity has been most frequently invoked in the context of antitrust litigation. ${ }^{2}$ The statute is

1 15 U.S.C. $\$ \S 1011-1015$ (1976). The statutory language provides in part:

$\S 1011$

The Congress hereby declares that the continued regulation and taxation by the several States of the business of insurance is in the public interest, and that silence on the part of the Congress shall not be construed to impose any barrier to the regulation or taxation of such business by the several States.

$\S 1012$

(a) The business of insurance, and every person engaged therein, shall be subject to the laws of the several States which relate to the regulation or taxation of such business. (b) No Act of Congress shall be construed to invalidate, impair, or supersede any law enacted by any State for the purpose of regulating the business of insurance, or which imposes a fee or tax upon such business, unless such Act specifically relates to the business of insurance: Provided, That after June 30,1948, the Act of July 2, 1890, as amended, known as the Sherman Act, and the Act of October 15, 1914, as amended, known as the Clayton Act, and the Act of September 26, 1914, known as the Federal Trade Commission Act, as amended, shall be applicable to the business of insurance to the extent that such business is not regulated by State law.

${ }^{2}$ In the academic commentary, the focus has been on the proviso holding the Sherman, Clayton, and Federal Trade Commission Acts "applicable to the business of insurance to the extent that such business is not regulated by State law." The major issues raised by this proviso have been the scope of the term "business of insurance" and the level of state regulation required to trigger the McCarran-Ferguson exemption. See Note, The Definition of "Business of Insurance" Under the McCarran-Ferguson Act After Royal Drug, 80 Colum. L. Rev. 1475 (1980) [hereinafter cited as Columbia Note]; Comment, Federal Regulation of Insurance Companies: The Disappearing McCarran Act Exemption, 1973 Duke L.J. 1340 [hereinafter cited as Duke Comment]; Note, Qualified Immunity for Insurers Under the McCarran-Ferguson Act, 46 Geo. WASH. L. Rev. 396 (1978) [hereinafter cited as George Washington Note]; Comment, The McCarran Act's Antitrust Exemption for "The Business of Insurance": A Shrinking Umbrella, 43 TENN. L. REv. 329 (1976) [hereinafter cited as Tennessee Comment]; Comment, State Regulation Under the McCarran Act, 47 TuL. L. Rzv. 1069 (1973) [hereinafter cited as Tulane Comment]. The literature on the McCarranFerguson Act's antitrust implications is voluminous. See generally Hanson, The Interplay of the Regimes of Antitrust, Competition and State Insurance Regulation of the Business of Insurance, 28 Drake L. REv. 767 (1979); National Institute Proceedings: Application of Antitrust Law to the Business of Insurance, 13 Forum 867 (1978); Nedrow, The McCarran Controversy: Insurance and the Antitrust Law, 12 Cons. L. Rev. 205 (1980); Stern, The McCarran Act 20 Years After, 1966 Ins. L.J. 605; Comment, The McCarran-Ferguson Act: A Time for Procompetitive Reform, 29 VAND. L. REv. 1271 (1976) [hereinafter cited as Vanderbilt Comment]. 
broadly worded, however, and extends the immunity of the insurance industry beyond the antitrust context to all other areas of federal regulation not specifically aimed at the "business of insurance."3 Despite this broad grant of immunity, courts often have been reluctant to give full effect to the plain language of the statute when parties have sought to invoke McCarran-Ferguson immunity in areas other than antitrust. This comment examines and criticizes the interpretation that courts have given the McCarranFerguson Act in two significant nonantitrust contexts: cases arising under the Truth in Lending Act ${ }^{4}$ and under Title VII of the Civil Rights Act of 1964.

The comment first reviews the legislative history of the statute, which indicates that while Congress generally intended to grant the insurance industry a comprehensive exemption from federal regulation, it failed to delineate the scope of this exemption. Next, it analyzes the interpretation that has been given to the phrase "the business of insurance" in cases arising under the Truth in Lending Act and Title VII, concluding that some courts have impermissibly narrowed the range of activities covered under this term. The comment also analyzes judicial interpretations of the second requirement for McCarran-Ferguson immunity-that the federal statute "invalidate, impair, or supersede" state law regulating the business of insurance-and shows that courts have not yet applied this language properly. Finally, the comment concludes that the plain language of the McCarran-Ferguson Act exempts the business of insurance from federal regulation in contexts where such immunity seems undesirable because it poses an obstacle to the important federal policies embodied in the Truth in Lending Act and Title VII; if Congress did intend those statutes to apply to the insurance industry, however, it should act to make its intention clear. ${ }^{7}$

3 Despite the broad grant of immunity in section 1012(b), see note 1 supra, certain federal statutes are specifically exempted from the effect of the McCarran-Ferguson Act:

Nothing contained in this Act shall be construed to affect in any manner the application to the business of insurance the Act of July 5, 1935, as amended, known as the National Labor Relations Act, or the Act of June 25, 1938, as amended, known as the Fair Labor Standards Act of 1938, or the Act of June 5, 1920, known as the Merchant Marine Act, 1920.

15 U.S.C. § 1014 (1976). See also text and note at note 28 infra.

15 U.S.C. $\S \S 1601-1665$ (1976).

s 42 U.S.C. $\$ \S 2000 \mathrm{e}-2000 \mathrm{e}-17$ (1976 \& Supp. II 1978).

- 15 U.S.C. \$ 1012(b) (1976).

- Statutes such as Title VII could be amended to state that they relate specifically to 


\section{The History of the Act}

Congress enacted the McCarran-Ferguson Act in $1945^{8}$ in response to the Supreme Court's decision in United States v. SouthEastern Underwriters Association. ${ }^{\circ}$ Overturning precedent, ${ }^{10}$ the Court held that the business of insurance was within the scope of the interstate commerce clause and thus subject to regulation under the federal antitrust laws. ${ }^{11}$ This decision rendered the business of insurance vulnerable to the full scope of federal regulation, contrary to the then generally accepted principle that the insur-

the business of insurance. Alternatively, section 1014 of the Act could be amended to make the McCarran-Ferguson Act immunity unavailable in Truth in Lending and Title VII cases. Finally, the more drastic action of repealing the McCarran-Ferguson Act, or at least its applicability to nonantitrust cases, is of course open to Congress.

In fact, legislation introduced in the 96th Congress would have substantially amended the Act and restricted its effect to certain specific business practices. S. 2474, 96th Cong., $2 \mathrm{~d}$ Sess. (1980). Section 6(a) of S. 2474 specifically prohibits sex discrimination of the type alleged in the Spirt and Peters cases, see text and notes at notes 83-87 infra. The general immunity language of section 1012(b) is deleted entirely from S. 2474. See also Comment, Potential Federal Intervention in the Insurance Industry: The Pending United States Senate Subcommittee Draft to Amend the McCarran-Ferguson Act, 28 Drakz L. Rzv. 926 (1979).

For conflicting views on the relative advantages of federal or state regulation, compare Kimball, The Case for State Regulation of Insurance, in INSURANCE, GovernmenT, AND Social Pourcy 411 (S. Kimball \& H. Denenberg eds. 1969) with McHugh, The Real Issue: State versus Federal or Regulation versus Competition, in id. at 193.

The majority of the literature generated by this proposed legislation has dealt not with the policy conflict explored in this comment but with the modification or repeal of the exemption from an antitrust perspective. As to modification, see, e.g., 2 National Commission for the Review of Antitrust Laws and Procedures, Report to the Prbsident and the Attorney General 225-52 (1979) [hereinafter cited as Report to the President]; McHugh, The McCarran Act Shield: Its Origin, Evolution, and Future, 13 Forum 630 (1978); Comments on the Repeal or Amendment of the McCarran-Ferguson Act, 48 ANTTTRUST L.J. 997 (1980); Vanderbilt Comment, supra note 2. But see Hanson, The Disadvantages of Federal Insurance Regulation as Highlighted by the Brooke Bill, 13 Forum 605 (1978); Hanson, supra note 2; Whiting, The Case for Retaining the Exemption, 13 Fonum 927 (1978). Concerning the antitrust implications of repeal, see Fedrral-State Regulation Or THE Pricing and Marketing of Insurance 41-64 (P. MacAvoy ed. 1977); Hanson, supra note 2, at 81787; Joskow, Competition and Regulation in the Property/Casualty Insurance Industry, in 2 Report to The President, supra, at 207-27.

8 Ch. 20, 59 Stat. 33 (1945) (codified at 15 U.S.C. $\$ \S 1011-1015$ (1976)).

- 322 U.S. 533 (1944). The South-Eastern Underwriters Association, its membership of nearly 200 private-stock fire insurance companies, and various individuals were indicted for alleged violations of the Sherman Act. The indictment alleged two conspiracies: the first to restrain and the second to monopolize interstate trade and commerce by fixing and maintaining arbitrary and noncompetitive premium rates on fire and specified "allied lines" of insurance in seven southern states. Id. at 534-35.

${ }^{10}$ E.g., New York Life Ins. Co. v. Deer Lodge County, 231 U.S. 495 (1913).

11322 U.S. at 561. 
ance industry was immune from federal regulation and subject only to the regulation of the individual states. ${ }^{12}$

The furor that followed the South-Eastern Underwriters decision and culminated in the passage of the McCarran-Ferguson Act was prompted by a variety of concerns. Proponents of the Act perceived South-Eastern Underwriters as striking "at.the heart of State sovereignty"1s and leading to an undesirable concentration of power in Washington. ${ }^{14}$ It was feared that the decision would interfere with state taxation, ${ }^{16}$ broaden the reach of federal bureaucracy, ${ }^{16}$ and cause chaos in an industry that had developed certain necessarily noncompetitive practices-such as cooperative rate making-under the protective umbrella of state regulation. ${ }^{12}$ Insurance companies were particularly concerned that the decision could place them in a double bind. If they continued to engage in practices such as cooperative rate making, as required by state law, they might be subject to federal antitrust prosecution; if they abandoned such practices, they would be violating state law.18 Consequently, the drafters of the McCarran-Ferguson Act sought to restore the regulatory structure of the insurance industry to its pre-South-Eastern Underwriters status, ${ }^{19}$ thereby honoring Con-

12 Until the South-Eastern Underwriters decision, the insurance industry was not considered to be part of interstate commerce and thus was subject only to regulation by individual states. Once South-Eastern Underwriters held the industry to be involved in interstate commerce, it was feared that the existing system of state taxation and regulation would be held to be an unlawful restraint of interstate commerce. H.R. REP. No. 873, 78th Cong., 1st Sess. 6, 10 (1943); 90 CoNG. Rec. 6527-48 (1944). As some individual states derived very substantial revenues from taxation of the insurance industry, there was considerable sentiment that the situation should be returned to pre-South-Eastern Underwriters status. 90 CoNG. REc. 6548 (1944) (remarks of Rep. Cravens). Justice Jackson, dissenting in part in the South-Eastern Underwriters case, stated: "The Court's decision at very least will require an extensive overhauling of state legislation relating to taxation and supervision. . . . Certainly the states lose very important controls and very considerable revenues." 322 U.S. at 590 (footnote omitted).

1390 Cong. Rec. 6559 (1944) (remarks of Rep. Sumners).

14 Id. at 6530 (remarks of Rep. Satterfield); id. at 6536 (remarks of Rep. Howell).

${ }^{15}$ Id. at 6548 (remarks of Rep. Cravens).

18 H.R. Rep. No. 873, 78th Cong., 1st Sess. 6 (1943).

1789 CoNG. Rec. 10661 (1943) (remarks of Rep. Miller).

18 S. REP. No. 20, 79th Cong., 1st Sess. 2 (1945); 90 Cong. REc. 6526 (1944) (remarks of Rep. Walter).

10 91 Cong. Rec. 1442 (1945) (remarks of Sen. McCarran). See also Prudential Ins. Co. v. Benjamin, 328 U.S. 408, 429-31 (1945). By enacting the McCarran-Ferguson Act, Congress did not completely restore the regulatory structure of the insurance industry to that existing prior to the South-Eastern Underwriters decision. The major differences are in the antitrust area. Most importantly, the McCarran-Ferguson Act provides that the Sherman Act does apply to agreements or acts to "boycott, coerce, or intimidate." 15 U.S.C. $\$ 1013$ (b) 
gress's original intention, when enacting the Sherman ${ }^{20}$ and Clayton $^{21}$ Acts, to exclude the insurance industry from their scope. ${ }^{22}$

Even prior to the decision in South-Eastern Underwriters, legislation that sought to preserve the insurance industry's immunity from potential judicial abrogation had been introduced in both houses of Congress. ${ }^{23}$ These early versions of the legislation were extremely brief, providing simply that the Sherman and Clayton Acts were not to be construed as applicable to the business of insurance. ${ }^{24}$ The final version of the legislation, introduced ${ }^{25}$ and

(1976).

${ }^{20} 15$ U.S.C. $\S \S 1-7$ (1976).

${ }^{21}$ Id. §§ 12-27; 29 U.S.C. $\S \S 52-53$ (1976).

3290 Cong. REc. 6524 (1944) (remarks of Rep. Walter). The decisions of the Court indicating that the insurance business was not "commerce" apparently were known to the Senate. During the Senate debate over the original bill introduced by Senator Sherman, Senator Turpie, discussing the reach of the federal commerce power, stated, "I recollect one judicial decision upon this subject very definitely. The Supreme Court has decided that insurance is not commerce . . ." 21 CoNG. REc. 2556 (1890). The intention of Congress in enacting the Sherman Act and other antitrust legislation was, of course, one of the major issues in South-Eastern Underwriters.

${ }^{23}$ See 89 Cong. REc. 7686, 7689 (1943). During the almost two years from the time this legislation was introduced until similar legislation was enacted into law, much attention was focused on the progress of the legislation. It had the support of both major political parties. The 1940 platform of the Democratic Party contained the provision: "We favor strick [sic] supervision of all forms of the insurance business by the several States for the protection of policyholders and the public." Quoted in H.R. REp. No. 873, 78th Cong., 1st Sess. 11 (1943). The Republican Party platform of 1940 stated: "We condemn the New Deal attempts to destroy the confidence of our people in private insurance institutions. We favor a continuance of regulation of insurance by the several states." Quoted in id.

Neither the insurance industry, see Insurance, Joint Hearings on S. 1362, H.R. 3269, and H.R. 3270 Before the Subcomms. of the Comms, on the Judiciary, 78th Cong., 1st Sess. 73 (1943) (testimony of Edward L. Williams, president of the Insurance Executives Association), nor the state officials concerned with regulating the insurance industry, see S. REP. No. 1112, pt. 2, 78th Cong., 2d Sess. 5-6 (1944), were happy with the decision in SouthEastern Underwriters. They felt that the structure of state taxation and regulation that had developed to oversee one of the nation's largest industries was in danger of collapse with no immediate alternative at hand. See H.R. REp. No. 143, 79th Cong., 1st Sess. 203 (1945); S. REP. No. 20,79th Cong., 1st Sess. 2 (1945). For a contemporary history, see Comment, $A$ Year of S.E.U.A., 23 ChI.-Kent L. REv. 317 (1945). For a general history, see Carlson, The Insurance Exemption from the Antitrust Laws, 57 TEx. L. REv. 1127 (1979); Weller, The McCarran-Ferguson Act's Antitrust Exemption for Insurance: Language, History and Policy, 1978 Duke L.J. 587.

${ }^{24}$ H.R. 3270 and the identical S. 1362 were introduced in the first session of the 78th Congress and provided:

That nothing contained in the Act of July 2, 1890, as amended, known as the Sherman Act, or the Act of October 15, 1914, as amended, known as the Clayton Act, shall be construed to apply to the business of insurance or to acts in the conduct of that business or in any wise to impair the regulation of that business by the several states. 
eventually enacted ${ }^{26}$ in the Seventy-Ninth Congress, was more explicit and significantly broader in scope. ${ }^{27}$ The comprehensive immunity granted by section 1012(b) of the Act was a feature of both the Senate and House versions. Senator O'Mahoney, one of the comanagers of the bill, endorsed a broad view of the general grant of immunity in the Act, stating that it should be interpreted not merely "as an additional exemption from the Antitrust laws," but rather as a "catch-all provision to take into consideration other acts of Congress which might affect the insurance industry, but of which we did not have knowledge at the time."28

The McCarran-Ferguson Act intentionally embraced the full scope of possible federal regulation. ${ }^{29}$ It is also evident that neither the Senate nor the House sufficiently considered the ramifications of such an extension. In fact, the only areas to receive appreciable attention were those that gave the primary impetus for the Act:

S. Rsp. No. 1112, pt. 2, 78th Cong., 2d Sess. 1-2 (1944). This bill passed the House, 90 Cong. REC. 6565 (1944), but failed to pass the Senate, 90 CoNG. REc. 8054 (1944). The bill's failure in the Senate is attributable in part to the desire of some Senators that no legislation be enacted before the National Association of Insurance Commissioners ("NAIC") (an organization of state officials who administer state insurance regulations) submitted its version of the bill. S. RgP. No. 1112, pt. 2, 78th Cong., 2d Sess. 6 (1944). See also Weller, supra note 21 , at $592-93$ \& n.34.

${ }^{2 s}$ H.R. 1973, 79th Cong., 1st Sess. (1945); S. 340, 79th Cong., 1st Sess. (1945).

26 91 CoNG. Rec. 1085, 1396 (1945).

${ }^{27}$ S. 340 and H.R. 1973 were modifications of the bill originally drafted by the legislative committee of the NAIC. 91 CoNG. REc. 483 (1945) (remarks of Sen. O'Mahoney). See also Weller, supra note 23 , at 587, 593-97.

${ }^{28} 91$ CoNG. RBC. 483 (1945). Senator O'Mahoney's remarks pertained to his bill, S. 12, which, in fact, was more restrictive than the legislation eventually enacted by Congress. Similarly, in the Senate debate over passage of S. 340, both Senator Ferguson and Senator Rivercomb explicitly confirmed that the intent of the bill was to exempt the insurance industry from future federal statutes, whether they pertained to antitrust or other areas of federal concern. Id.

Despite such explicit recognition of the broad scope of immunity contained in section 1012(b), there was no debate over this aspect of the Act. There was debate, however, over the operational effect of the statute in the antitrust context. As a result, the conference version of the bill that was adopted, see 91 CoNG. REc. 1085, 1396 (1945), differed substantially from the original Senate and House versions. Among other differences, the original versions exempted the insurance industry from the Federal Trade Commission Act, while the enacted conference bill made that act applicable, after a brief moratorium, to the insurance industry to the extent that it was not regulated by state law. See H.R. REP. No. 213, 79th Cong., 1st Sess. 3 (1945); Weller, supra note 23, at 597 n.56.

2* A number of cases construing the Act have recognized the breadth of the immunity. In one of the first cases to be decided following passage of the Act, the Supreme Court stated: "Obviously Congress' purpose was broadly to give support to the existing and future state systems for regulating and taxing the business of insurance." Prudential Ins. Co. v. Benjamin, 328 U.S. 408, 429 (1946). See also Cochran v. Paco, Inc., 606 F.2d 460, 463 (5th Cir. 1979). 
state taxation and federal antitrust regulation. ${ }^{30}$ Analysis of the statute's application to nonantitrust areas must therefore be undertaken without the benefit of expressly applicable legislative history.

\section{The Case Law}

The plain language of the statute indicates that a party in the business of insurance ${ }^{31}$ may claim McCarran-Ferguson immunity from any federal regulation not specifically relating to insurance whenever the application of federal law would "invalidate, impair, or supersede" state law..$^{32}$ Consequently, when a party attempts to invoke McCarran-Ferguson immunity, three determinations are necessary: (1) whether the federal statute involved "specifically relates to the business of insurance"; (2) if not, whether the activity in question is within the "business of insurance"; and (3) if so, whether the application of federal law would "invalidate, impair, or supersede" state law. While the first question lends itself to relatively easy resolution, ${ }^{33}$ courts are in conflict over the latter two

so Virtually all debate concerning the McCarran-Ferguson exemption focused on the interplay between state and federal law in the antitrust context. 90 CoNG. REc. 6524-56 (1944); 91 CoNG. REC. 479-80, 484, 486 (1945). Considerable concern was expressed over the states' ability to preempt federal antitrust policy by the enactment of their own insurance regulatory laws. 91 CoNG. REc. 479 (1945) (remarks of Sens. Murdock \& Ferguson). Once the South-Eastern Underwriters decision was announced, the pressures on Congress to act promptly increased because of the threat that many insurance companies would refuse to pay "state taxes on the ground that such levies were burdens on interstate commerce. S. REP. No. 20, 79th Cong., 1st Sess. 2 (1945); 91 Cong. REc. 484, 1087, 1092 (1945).

The Senate and House reports on the final bills both state that one purpose of the bill was " $[t] 0$ declare that the continued regulation and taxation by the several States of the business of insurance is in the public interest." H.R. REP. No. 68, 79th Cong., 1st Sess. 2 (1945); S. REP. No. 20, 79th Cong., 1st Sess. 2 (1945).

31 There is some dispute over whether this language encompasses entities other than insurance companies. See note 56 infra.

3215 U.S.C. $\S 1012$ (b) (1976).

${ }^{33}$ This first step in McCarran-Ferguson analysis has never been a matter of serious contention. Some plaintiffs have argued that the lack of an express omission of the insurance industry from the scope of a particular statute is the same as an affirmative provision that it "specifically relates" to insurance, but this argument has never been taken seriously. See Cochran v. Paco, Inc., 606 F.2d 460, 464 (5th Cir. 1979).

The meaning of the phrase is illustrated by section 1014 of the McCarran-Ferguson Act itself. This section "specifically relates" the National Labor Relations Act and the Fair Labor Standards Act to the business of insurance. Id. at 464. The remarks of Senator Ferguson also shed light on the meaning of the phrase:

If there is on the books of the United States a legislative act which relates to interstate commerce, if the act does not specifically relate to insurance, it would not apply at the present time. Having passed the bill now before the Senate, if Congress should to- 
questions in the contexts of the Federal Truth in Lending Act and Title VII of the Civil Rights Act of 1964.

\section{A. The Business of Insurance}

The legislative history of the Act offers little guidance in interpreting the phrase "the business of insurance." islative history indicates that "Congress' purpose was broadly to give support to the existing and future state systems for regulating and taxing the 'business of insurance," "\$s it fails to reveal exactly what that term was intended to embrace. ${ }^{38}$

The Supreme Court's major pronouncement on the subject provides a general interpretation of the term "business of insurance," but it, too, fails to delineate its scope adequately. In $S E C v$. National Securities, Inc., ${ }^{37}$ the Court stated that in passing the McCarran-Ferguson Act, "Congress was concerned with the type of State regulation that centers around the contract of insurance. ... The relationship between insurer and insured, the type of policy which could be issued, its reliability, interpretation, and enforcement-these were the core of the 'business of insurance.' "ss As examples, the Court cited such activities as the fixing of rates, the selling and advertising of policies, and the licensing of companies and their agents. ${ }^{39}$ In a recent decision involving the $\mathrm{Mc}$ -

morrow pass a law relating to interstate commerce and should not specifically apply the law to the business of insurance, it would not be an implied repeal of this bill, and this bill would not be affected, because the Congress had not, under subdivision (b), said that the new law specifically applied to insurance.

91 Cong. Rec. 481 (1945).

st See SEC v. National Sec., Inc., 393 U.S. 453, 458 (1968).

ss Prudential Ins. Co. v. Benjamin, 328 U.S. 408, 429 (1945).

${ }^{36}$ One version of the legislation proposed by the NAIC enumerated specific practices that were to be exempted from federal regulation. This more specific form of the legislation was rejected in favor of the generalized exemption language that was enacted. See Group Life \& Health Ins. Co. v. Royal Drug Co., 440 U.S. 205, 221-23 (1979).

${ }^{37} 393$ U.S. 453 (1968). In this case, the Court addressed the SEC's power to regulate the merger of two insurance companies. The Court held that the Act did not preclude the application of rule $10 \mathrm{~b}-5$ disclosure requirements to this merger, noting that the case involved questions concerning the relationship between a stockholder and the company in which he holds stock rather than the insurance relationship which is at the core of the McCarran-Ferguson Act. Commenting on the phrase "the business of insurance," the Court stated that "whatever the exact scope of the statutory term, it is clear where the focus was-it was on the relationship between the insurance company and the policyholder. Statutes aimed at protecting or regulating this relationship, directly or indirectly, are laws regulating the "business of insurance." "Id. at 460.

ss Id. at 460 .

so Id. 
Carran-Ferguson Act, Group Life \& Health Insurance Co. v. Royal Drug Co., ${ }^{40}$ the Court reaffirmed the delineation of the business of insurance articulated in National Securities. ${ }^{\mathbf{1 1}}$

1. Truth in Lending Cases. The Seventh Circuit, in Lowe $v$. Aarco-American, Inc., ${ }^{42}$ read the phrase "the business of insurance" broadly. In that case, Aarco-American, an insurance broker, and Fairway Acceptance Company, a company that provided premium financing ${ }^{43}$ in connection with the sale of insurance policies, were accused of violating the disclosure requirements of the Truth in Lending Act. The defendant companies moved to dismiss the claim on the ground that they were engaged in the business of insurance, an activity regulated by the state of Illinois, and consequently that the application of the Truth in Lending Act to their activities would supersede Illinois law in contravention of the McCarran-Ferguson Act. ${ }^{44}$

The Seventh Circuit affirmed the trial court's ruling in the defendants' favor, holding that the credit sale of insurance policies was an activity encompassed within the scope of the business of insurance. The court stated that the business of insurance embraced "more than questions of the validity and enforceability of insurance policies or the limits of policy coverages."4s The court reasoned that premium financing was similar to the setting of a company's rate structure and thus included within the McCarranFerguson exemption. ${ }^{46}$

10440 U.S. 205 (1979). The Court held agreements between Blue Shield of Texas and pharmacies to fix retail prices of drugs (so-called "provider agreements") not to be within the scope of the business of insurance and thus not immune under the McCarran-Ferguson Act from prosecution under the Sherman Act. Id. at 214-17.

11 Id. at 215-16. The dissenting Justices in Royal Drug felt that the majority opinion had unduly restricted the holding in National Securities. Id. at 233 (Brennan, J., dissenting). It is noteworthy that this dissent was joined by Justice Marshall, who had written the opinion for the Court in National Securities.

12536 F.2d 1160 (7th Cir. 1976).

4s Generally, a financed insurance policy is no different from a traditional insurance arrangement, except that the insured party pays the premium for the policy in installments over the life of the policy, and either the insurance company or an independent finance company receives an interest payment over and above the insurance premium, in return for advancing the funds to pay the premium. See Krischer, "Truth" in Insurance Premium Financing, 30 Bus. Law. 969, 971-72 (1975); Comment, Insurance Premium Financing, 19 Buffalo L. Rev. 656 (1970).

14 See 536 F.2d at 1161 .

48 Id. at 1162.

${ }^{18}$ Id. This argument was first articulated in Gerlach v. Allstate Ins. Co., 338 F. Supp. 642 (S.D. Fla. 1972). The court in Gerlach granted the defendant insurance company summary judgment against the plaintiff's Truth in Lending Act claim on the ground that the 
The Fifth Circuit, in a recent trilogy of cases involving the Truth in Lending Act, departed sharply from the reasoning in Lowe and offered a narrower interpretation of the term "business of insurance." ${ }^{47}$ In Perry v. Fidelity Union Life Insurance Co. ${ }^{48}$ as in Lowe, the defendant was accused of violating the disclosure requirements of the Truth in Lending Act in connection with the premium financing of insurance policies. ${ }^{4}$ The Perry court held that premium financing by an insurance company did not constitute the business of insurance within the meaning of the McCarran-Ferguson Act; ${ }^{\text {;0 }}$ such financing activity was found to be "purely ancillary to the insurance relationship between the insurance company and the policyholder." surance company that offered premium financing as a sales inducement to be involved in two distinct roles, one as a creditor and the other as an insurer, and held that only in the insurer role was the company entitled to the protection of the McCarran-Ferguson Act. ${ }^{\text {s2 }}$ Reasoning by analogy to antitrust cases involving the Act, ${ }^{53}$

insurance agreement was not a consumer credit transaction within the scope of the Act. Id. at 648-49. In the alternative, the court found that Allstate's installment payment plan was part of its rate structure and thus within the Supreme Court's definition of the business of insurance in National Securities. Id. at 649; accord, Ben v. General Motors Acceptance Corp., 374 F. Supp. 1199, 1201 (D. Colo. 1974). Ben involved alleged violations of the Truth in Lending Act and the 1866 Civil Rights Act, 42 U.S.C. $\$ \S 1982,1985$ (1976), in the context of an insurance policy required as an incident to a loan made by the General Motors Acceptance Corporation. But see Krischer, supra note 43, at 976 (criticizing Gerlach); Tennessee Comment, supra note 2, at 358 (same).

47 Cochran v. Paco, Inc., 606 F.2d 460 (5th Cir. 1979); Perry v. Fidelity Union Life Ins. Co., 606 F.2d 468 (5th Cir. 1979), cert. denied, 100 S. Ct. 2973 (1980); Cody v. Community Loan Corp., 606 F.2d 499 (5th Cir. 1979), cert. denied, 100 S. Ct. 2973 (1980). For commentary taking the position that the general trend in cases interpreting the McCarran-Ferguson Act is toward a narrower interpretation of this phrase, see Duke Comment, supra note 2; George Washington Note, supra note 2; Tennessee Comment, supra note 2.

ts 606 F.2d 468 (5th Cir. 1979), cert. denied, 100 S. Ct. 2973 (1980).

49 See id. at 470. Although Perry involved an insurance company as defendant, rather than an independent premium financing agency as in Lowe, the Fifth Circuit did not find this distinction significant in its analysis. See also note 56 infra.

so 606 F.2d at 471. Cochran v. Paco, Inc., 606 F.2d 460 (5th Cir. 1979), involved a similar situation, except that the defendant was an independent premium finance company. In direct opposition to Lowe, the Fifth Circuit held that premium financing engaged in by an independent premium financing agency was not within the business of insurance. Id. at 467 . In Cody v. Community Loan Corp., 606 F.2d 499 (5th Cir. 1979), cert. denied, 100 S. Ct. 2973 (1980), the defendant was a household loan company that also financed and sold certain types of insurance. The Fifth Circuit applied the same principles as in Cochran and Perry, and concluded that the defendant's activities in Cody also were not within the business of insurance. Id. at 503.

83606 F.2d at 470 .

${ }^{6}$ Id. 
the court stated that any activity that was not "an integral part of the insurance business" and "peculiar to the insurance industry" was outside the scope of the business of insurance. ${ }^{54}$ The Fifth Circuit further noted, in Cochran v. Paco, Inc., ${ }^{55}$ that it failed to see how the type, reliability, interpretation, and enforcement of insurance policies, the elements of the insurer-insured relationship identified by the Supreme Court in the National Securities case as the core of the business of insurance, were "affected to any significant extent by premium financing arrangements."

ss The opinions of both the majority in Cochran and the dissent in Perry utilize McCarran-Ferguson Act cases from antitrust contexts as "guides for construing the terms of the statute" in nonantitrust cases. Cochran v. Paco, Inc., 606 F.2d 460, 463 (5th Cir. 1979); Perry v. Fidelity Union Life Ins. Co., 606 F.2d 468, 477 (5th Cir. 1979) (Brown, C.J., dissenting), cert. denied, $100 \mathrm{~S}$. Ct. 2973 (1980). As the usage of the phrase the "business of insurance" is similar in both the first and second sentences of section 1012(b), courts have tended to assume that the interpretation of this phrase is readily transferable from an antitrust context to a nonantitrust context.

s4 606 F.2d at 470 .

ss 606 F.2d 460 (5th Cir. 1979).

56 Id. at 466. See also Krischer, supra note 43, at 976. The Fifth Circuit's opinion in Cochran is not entirely consistent with its statement in Perry, however. Before concluding, consistently with Perry, that premium financing is not within the business of insurance, regardless of the nature of the defendant, 606 F.2d at 466-67, the Cochran court stated that "we must keep in mind that Paco is not an insurance company," id. at 465 . In a footnote, the court added: "At the outset we reject Paco's argument that under National Securities the McCarran Act exemption extends to people who are neither the insurance company nor the insured." Id. at 465 n.13. Chief Judge Brown, who had concurred in Cochran, indicated in his Perry dissent that the nature of the defendant was significant. Id. at 471, 484 n.35.

The two positions represent interpretations of the same phrase in National Securities: "The statute did not purport to make the States supreme in regulating all the activities of insurance companies; its language refers not to the persons or companies who are subject to state regulation, but to laws 'regulating the business of insurance." "SEC v. National Sec., Inc., 393 U.S. 453, 459 (1968) (emphasis in original). Because National Securities held only that noninsurance activities of insurance companies are not protected, the language of that case, like the language of the McCarran-Ferguson Act itself, is not dispositive of this issue.

There appears to be little justification, however, for looking to an organization's formal title or name as a basis for limiting the scope of the McCarran-Ferguson Act to insurance companies alone. In the past, there has been no question that other non-insurance company parties such as agents and brokers have been included within the scope of the McCarranFerguson immunity. See, e.g., Lowe v. Aarco-American, Inc., 536 F.2d 1160 (7th Cir. 1976), where the Seventh Circuit held that an insurance broker and an independent insurance premium financing company were within the McCarran-Ferguson Act exemption. See also Bartholomew v. Virginia Chiropractors Ass'n, 612 F.2d 812, 816-17 (4th Cir. 1979) (chiropractors who were members of commission that reviewed chiropractor bills submitted to insurance company for payment were, in that capacity, involved in the business of insurance); Manasen v. California Dental Servs., 424 F. Supp. 657 (N.D. Cal. 1976), rev'd on other grounds, [1979-1] Trade Cas. 77,069 (9th Cir. 1979). But see Providence Wash. Ins. Co., 89 F.T.C. 345,358 (1977); Krischer, supra note 43, at 976.

There are, however, reasonable economic arguments, based on the nature of the specific business transaction involved, that may support a distinction between an independent 
Chief Judge Brown, dissenting in Perry, embraced the more expansive interpretation given to the scope of the business of insurance in Lowe. The dissent disagreed with the majority's conclusion that premium financing was ancillary to the business of insurance, because such financing serves as an inducement to purchase insurance and is integrally related to the sale of the policy. ${ }^{57}$ Premium financing, the dissent therefore maintained, was an activity fully within the definition of the insurer-insured relationship described by the Supreme Court in National Securities. ${ }^{58}$ Chief Judge Brown further argued that the Fifth Circuit's finding that premium financing was not an activity peculiar to the insurance industry was based on a misinterpretation of the "peculiar activity" standard used in the antitrust cases cited by the majority. ${ }^{.9}$ $\mathrm{He}$ noted that the majority's failure to characterize premium financing as an activity peculiar to the insurance industry would, by implication, leave a whole range of activities, such as rate making and advertising, outside the scope of the business of insurance. ${ }^{60}$

premium financing agency and other non-insurance company parties such as insurance agents. When a premium finance company is involved, the insurer does not bear the risk of nonpayment. The premium typically is prepaid at periodic intervals or paid in full at the outset of the policy period. If the insured defaults, the premium financer has an action against the insured, but the insurance company itself would have no interest in the matter. Perry v. Fidelity Union Life Ins. Co., 606 F.2d 468, 472 (5th Cir. 1979) (Brown, C.J., dissenting), cert. denied, $100 \mathrm{~S}$. Ct. 2973 (1980). Thus it can be argued that an independent premium finance company is far less involved in the relationship between insurer and insured than, for example, insurance agents. See Providence Wash. Ins. Co., 89 F.T.C. 345 (1977).

${ }^{37} 606$ F.2d at 476. Chief Judge Brown noted that premium financing is analogous to advertising in terms of its role in the insurer-insured relationship. Although he did not cite FTC v. National Cas. Co., 357 U.S. 560 (1957), that case had held advertising to be within the business of insurance.

Further, the dissent stated that premium financing is more than a convenience. If poor consumers of insurance were required to seek outside sources such as banks or consumer finance companies for loans to cover the purchase of a policy, the interest rate would be significantly, if not prohibitively, higher. 606 F.2d at 477; accord, Comment, supra note 43, at $659-60$.

ss 606 F.2d at 478.

so See id. at 476. An earlier case, American Family Life Assurance Co. v. Planned Mktg. Ass'n, 389 F. Supp. 1141 (E.D. Va. 1974), had used the phrase "not peculiar" to mean the same thing as the Supreme Court's "peculiar" standard in National Securities.

606 F.2d at 476. The Fifth Circuit's position implicitly conflicts with such cases as FTC v. National Cas. Co., 357 U.S. 560 (1957) (per curiam), where the Court held that the FTC did not have authority to regulate the advertising practices of insurance companies in those states that regulated such practices under their own laws. Under the Fifth Circuit's analysis, National Casualty would be acting like an advertiser when it engaged in such types of promotional activities, and, contrary to the Supreme Court's decision, such activities would not be within the scope of the McCarran-Ferguson exemption. 
It is unclear whether interpretations of the scope of the business of insurance in the antitrust context can be fully applied, as in Perry, to nonantitrust cases. Recently, in Group Life \& Health Insurance Co. v. Royal Drug Co., ${ }^{61}$ the Supreme Court stated that the McCarran-Ferguson Act's primary purpose was to preserve state regulation of insurance companies and that the antitrust aspects of the legislation were only a secondary purpose of the Act. ${ }^{62}$ The Court's relegation of the antitrust exemption to a secondary purpose casts doubt upon the use of antitrust cases to interpret nonantitrust cases. ${ }^{63}$ Moreover, the Court has consistently adhered to the principle that both explicit and implicit exemptions from the antitrust laws are to be narrowly construed. ${ }^{64}$ Consequently, reasoning by analogy to antitrust cases to construe the McCarranFerguson Act in Truth in Lending and Title VII cases may lead to a more restrictive interpretation of the statute's grant of immunity than Congress intended. ${ }^{\mathrm{BS}}$

It is clear, however, that activities included within the scope of the business of insurance in the antitrust context should also be so included outside that setting. These antitrust precedents confirm the finding of the Seventh Circuit and Chief Judge Brown that premium financing is within the scope of the business of insurance. Different forms of tying arrangements, similar to financing agreements in that they are a means of inducing the purchase of an insurance policy, ${ }^{66}$ have been held to be within the scope of the

61 440 U.S. 205 (1979); see note 40 supra.

62 The Court stated:

There is no question that the primary purpose of the McCarran-Ferguson Act was to preserve state regulation of the activities of insurance companies, as it existed before the South-Eastern Underwriters case. . . The McCarran-Ferguson Act operates to assure that the States are free to regulate insurance companies without fear of Commerce Clause attack. The question in the present case, however, is one under the quite different secondary purpose of the McCarran-Ferguson Act-to give insurance companies only a limited exemption from the antitrust laws.

440 U.S. at $218 \mathrm{n} .18$ (emphasis in original).

63 See Columbia Note, supra note 2, at 1484.

et E.g., 440 U.S. at 231.

CS Principles of statutory construction suggest that the phrase "business of insurance" should be interpreted similarly in both antitrust and other contexts. See note 53 supra. Yet to the extent that courts have construed the phrase narrowly in antitrust cases to reflect the policies underlying the antitrust laws, see text and note at note 63 supra, such a limited reading should not be applied to nonantitrust contexts.

${ }^{68}$ See Perry v. Fidelity Union Life Ins. Co., 606 F.2d 468, 477 (5th Cir. 1979) (Brown, C.J., dissenting), cert. denied, 100 S. Ct. 2973 (1980). But see the Fifth Circuit's rejection of this theory, id. at 470 n.6 (distinguishing "required" from "voluntary" financing arrangements). Tying arrangements may also be subject to the Sherman Act under section 3 of the 
business of insurance. ${ }^{67}$ The promotional activities of insurance companies $^{68}$ and the relationship between insurance companies and their agents, ${ }^{68}$ both enabling links, like premium financing, in the relationship between insurer and insured, also have been held within the scope of the "business of insurance."

The business of insurance logically encompasses the full range of activities involved in an insurance relationship. In holding that an insurance company that finances the sales of its policies is acting as a creditor rather than an insurer and thus is not entitled to the immunity granted by the McCarran-Ferguson Act, the Fifth Circuit has adopted an unjustifiably narrow perspective ${ }^{70}$ that ignores the broad scope of activities held by prior decisions to be within the business of insurance.

2. Title VII Cases. The conflict over the scope of the business of insurance is further illustrated by two recent cases involving claims made under Title VII of the Civil Rights Act of 1964. In these cases, the Teacher's Insurance and Annuity Association ("TIAA") and College Retirement Equities Fund ("CREF") were sued for alleged sex discrimination. The suits challenged the use of sex-segregated tables in determining annuity benefits as a violation

McCarran-Ferguson Act, 15 U.S.C. $\S 1013$ (1976) (rendering the McCarran-Ferguson Act inapplicable to any "agreement to boycott, coerce, or intimidate"). Certain forms of tying arrangements have been so prosecuted by the Justice Department. See, e.g., United States v. Investors Diversified Servs., [1954] Trade Cas. 69,574 (D.C. Minn. 1954).

${ }^{67}$ Dexter v. Equitable Life Assurance Soc'y, 527 F.2d 233 (2d Cir. 1975); Addrisi v. Equitable Life Assurance Soc'y, 503 F.2d 725 (9th Cir. 1974), cert. denied, 420 U.S. 929 (1975); Mcllhenny v. American Title Ins. Co., 418 F. Supp. 364 (E.D. Pa. 1976); Mathis v. Auto Club Inter-Ins. Exch., 410 F. Supp. 1037 (W.D. Mo. 1976). See also Annot., 33 A.L.R. Fed. 608 (1977).

os SEC v. National Sec., Inc., 393 U.S. 453, 460 (1968); FTC v. National Cas. Co., 357 U.S. 560 (1958).

- SEC v. National Sec., Inc., 393 U.S. 453, 460 (1968); Card v. National Life Ins. Co., 603 F.2d 828 (10th Cir. 1979); Steinberg v. Guardian Life Ins. Co., 486 F. Supp. 122 (E.D. Pa. 1980); Black v. Nationwide Mut. Ins. Co., 429 F. Supp. 458 (W.D. Pa. 1977); cf. Zelson v. Phoenix Mut. Life Ins. Co., 549 F.2d 62 (8th Cir. 1977) (insurer-agent relationship protected to extent it affects insurer-insured relationship). But see American Family Life Assurance Co. v. Planned Mktg. Co., 389 F. Supp. 1141, 1146-47 (E.D. Va. 1974). While the lower courts are in general agreement, the Supreme Court recently has reserved judgment on whether "transactions between an insurer and its agents, including independent agents, are the 'business of insurance." " Group Life \& Health Ins. Co. v. Royal Drug Co., 440 U.S. 205, 224 n.32 (1979).

${ }^{70}$ As the Supreme Court stated in interpreting a different section of the McCarranFerguson Act, "[w] hile the legislative history does not point unambiguously to the answer, it provides no substantial support for limiting language that Congress itself chose not to limit." St. Paul Fire \& Marine Ins. Co. v. Barry, 438 U.S. 531, 550 (1977). 
of both Title VII ${ }^{71}$ and the equal protection clause of the fourteenth amendment. In both cases, the defendant TIAA asserted that the application of Title VII was barred by the McCarran-Ferguson Act.

In the first case, Spirt $v$. Teachers Insurance \& Annuity Association, ${ }^{72}$ the court held that the McCarran-Ferguson Act precluded the application of Title VII to TIAA. ${ }^{73}$ The court found that the challenged activity, the use of sex-segregated mortality tables in the computation of annuity benefits, was an integral aspect of the insurer-insured relationship and thus squarely within the scope of the business of insurance as defined by the Supreme Court in National Securities. ${ }^{74}$ The court further found that New York State had "pervasively regulated the subject of discrimination between policyholders" $"$ and, consequently, the application of Title VII would "invalidate, impair, or supersede" New York law. ${ }^{76}$

7I Although Title VII makes only discriminatory practices of an employer unlawful, courts have found Title VII to be applicable to TIAA-CREF. The remedial purpose of the statute, see Spirt v. Teachers Ins. \& Annuity Ass'n, 475 F. Supp. 1298, 1308 (S.D.N.Y. 1979), remanded, No. 79-7715 (2d Cir. Feb. 19, 1981), the degree of involvement TIAACREF has in the employer's activities, see Peters v. Wayne State Univ., 476 F. Supp. 1343, 1350 (E.D. Mich. 1979), appeal docketed, No. 79-1670 (6th Cir. Dec. 13, 1979), and the necessity of such an extension of Title VII's reach to avoid frustration of its purposes by an employer's delegation of such authority, Spirt, 475 F. Supp. at 1308, have all been given as reasons for holding TIAA-CREF to be an employer within the meaning of Title VII.

72475 F. Supp. 1298 (S.D.N.Y. 1979), remanded, No. 79-7715 (2d Cir. Feb. 19, 1981).

${ }^{7 s}$ The court first noted that Title VII did not specifically refer to insurance. Id. at 1301. Because TIAA was a fixed-annuity company and thus subject to investment risk, its activities were held to be within the scope of the McCarran-Ferguson Act. Id. at 1303.

On the other hand, the Spirt court held that this immunity was unavailable to CREF, because CREF was a variable-annuity company. Under the rationale of SEC v. Variable Annuity Co., 359 U.S. 65 (1959), such companies were not insurance companies within the meaning of the McCarran-Ferguson Act. 475 F. Supp. at 1302-03.

74475 F. Supp. at 1302.

75 Id. at 1303-04. New York had enacted a comprehensive insurance code. In particular, section 209 of the New York code, N.Y. Insurance Law § 1-631 (McKinney 1966), provided that no life insurance company doing business in the state could make or permit any unfair discrimination between individuals of the same class and of equal expectations of life in premiums, rates, dividends, or benefits of policies.

${ }^{78}$ Id. See also text and notes at notes 88-118 infra. The McCarran-Ferguson Act was not raised as a defense to the equal protection claims raised in Spirt under sections 1983 and 1985(3). Both these claims failed for lack of the required state action. $475 \mathrm{~F}$. Supp. at $1313,1315$.

Equal protection claims under sections 1982 and 1985 also were raised in Ben v. General Motors Acceptance Corp., 374 F. Supp. 1199 (D. Colo. 1974). The plaintiff in Ben alleged that she had been placed in a high-risk auto insurance category solely because she was a Navajo Indian. The court held that the McCarran-Ferguson Act did not bar these claims. The holding was based on peculiar reasoning. The court found that the differences in background and history between the Civil Rights Acts and the McCarran-Ferguson Act demon- 
In Peters $v$. Wayne State University, ${ }^{77}$ a case involving issues similar to those raised in Spirt, the court rejected the claim of McCarran-Ferguson immunity raised by TIAA in a posttrial brief. ${ }^{78}$ The court asserted that TIAA did not have an investment risk (a necessary condition for insurance company status), ${ }^{79}$ a conclusion unsupported by any evaluation of the nature of TIAA's actual business. ${ }^{80}$ The court also found that TIAA was not in the business of insurance because TIAA was "so intertwined" with the institutions it served that it more closely resembled an employer than an insurance company. ${ }^{81}$

The Peters decision is a puzzling departure from precedent. There is no basis for the court's statement that TIAA does not have an investment risk. It is a well-established principle that the "primary elements of an insurance contract are the spreading and underwriting of a policyholder's risk." "82 The fixed annuity contracts sold by TIAA perform precisely that function. ${ }^{83}$ The guaranteed future payment received by a TIAA annuitant is precisely the "guarantee of fixed income" involving "some investment risk taking on the part of the company" that the Supreme Court has held

strated that Congress "in enacting the McCarran Act had no intent to deny access to the Federal Courts for redress for violations of a person's civil rights guaranteed by the Federal Constitution." Id. at 1202 . Although serious constitutional conflicts may be raised by an attempt to immunize insurance companies against claims under the fourteenth amendment (as implemented by the damage remedy of the Civil Rights Acts) by means of the McCarran-Ferguson Act, the language of the Act implies such an immunity. The court in Ben appears to have avoided this serious conflict by employing the simple, but hardly tenable, rationale that because there is no indication that Congress intended McCarran-Ferguson to provide such a broad immunity, the language of the Act alone cannot be construed to reach such a result, $i d$. at 1203 .

77476 F. Supp. 1343 (E.D. Mich. 1979), appeal docketed, No. 79-1670 (6th Cir. Dec. 13, 1979).

78 Id. at 1350.

79 The Supreme Court has interpreted the word "insurance" under the McCarran-Ferguson Act to require some investment risk on the part of the insurance company. SEC v. Variable Annuity Life Ins. Co., 359 U.S. 65, 71 (1959). See also note 73 supra.

so See 476 F. Supp. at 1351.

s1 Id. The court found it relevant that the contribution to TIAA's annuity plans was the mandatory subject of collective bargaining in many instances. Id.

${ }^{82}$ Group Life \& Health Ins. Co. v. Royal Drug, 440 U.S. 205, 211 (1979); accord, SEC v. Variable Annuity Life Ins. Co., 359 U.S. 65, 71-72 (1959).

ss The annuitant pays to the company a set yearly fee in exchange for the company's promise to pay the annuitant a guaranteed annuity once he reaches a specified age. EEOC $v$. Colby College, 589 F.2d 1139, 1141 (1st Cir. 1978). If the company calculates correctly, the premiums paid by the policyholders whose deaths occur earlier than predicted by actuarial statistics help pay the benefits of those who live longer. See Group Life \& Health Ins. Co. v. Royal Drug Co., 440 U.S. 205, 239 (1979) (Brennan, J., dissenting). 


\section{to be the crucial element of an insurance contract. $^{84}$}

The finding of the Peters court that TIAA is closely intertwined with the institutions it serves is irrelevant to whether TIAA is in the business of insurance for purposes of the McCarran-Ferguson Act. There is neither precedent nor legislative history indicating that a party otherwise engaged in the business of insurance loses that status when its relationship with its insured arises as the result of a three-way agreement between the insured, the insured's employer, and the insurance company. ${ }^{85}$

Because both the plain language of the statute and the relevant case law clearly encompass a situation such as Peters, ${ }^{86}$ the court's rejection of McCarran-Ferguson immunity may represent a conclusion that the policies behind Title VII should not be thwarted by recognition of the McCarran-Ferguson Act defense. ${ }^{87}$

84 SEC v. Variable Annuity Life Ins. Co., 359 U.S. 65, 71 (1959). See also Mearns, The Commission, the Variable Annuity and the Inconsiderate Sovereign, 45 VA. L. REv. 831, 840 (1959) (noting that the mortality risk inherent in a variable annuity contract might justify treating the annuity company as an insurer).

${ }^{85}$ There is, however, precedent for the contrary proposition. See, e.g., Ackerman-Chillingworth Div. of Marsh \& McLennan, Inc. v. Pacific Elec. Contractors Ass'n, 405 F. Supp. 99 (D. Hawaii 1975) (arrangement involving group insurance plan as element of the contract between various electrical contractors and unions; the insurance company was exempted from Sherman Act liability by the McCarran-Ferguson Act), aff'd, 579 F.2d 484 (9th Cir. 1978), cert. denied, 439 U.S. 1089 (1979).

${ }^{8 B}$ But see Case Comment, 68 GEo. L.J. 1285 (1980), arguing that Title VII can be deemed applicable to insurers, despite the McCarran-Ferguson Act, either on the theory that Title VII specifically relates to the business of insurance or by construing Title VII impliedly to repeal the McCarran-Ferguson Act.

Neither of these arguments is persuasive. The Arbitration Act cases, see text and notes at notes 97-102 infra, reject the theory that a law of general applicability specifically relates to the business of insurance within the meaning of the McCarran-Ferguson Act. More fundamentally, if the "specifically relates" inquiry is to turn on the "pervasive scope" of the federal legislation, see Case Comment, supra, at 1293, one might argue that federal antitrust laws specifically relate to the insurance industry. Such a result is clearly contrary to the intent of the McCarran-Ferguson Act framers.

The implied repeal cases relied on by the commentator, id. at 1294 n.90, themselves argue against application of the doctrine in this situation. For example, in TVA v. Hill, 437 U.S. 153 (1978), the court repeats the "cardinal rule . . . that repeals by implication are not favored." Rather, "the intention of the legislature to repeal must be clear and manifest." Id. at 189.

${ }^{87}$ The court in Dunn v. Midwestern Indem. MidAm. Fire \& Cas. Co., 472 F. Supp. 1106 (S.D. Ohio 1979), engages in a similar process, but with greater candor. In Dunn, the defendant insurance company sought to interpose a McCarran-Ferguson Act defense to the plaintiff's charge that insurance redlining by the defendant was a violation of the Fair Housing Act. Id. at 1111. The court rejected this defense, stating simply that the McCarran-Ferguson Act was not intended to address the problem of insurance redlining and hence was inapplicable. Id. at 1112. See also Ben v. General Motors Acceptance Corp., 374 F. Supp. 1199 (D. Colo. 1974). 


\section{B. Invalidate, Impair, or Supersede}

The second part of the McCarran-Ferguson Act inquiry requires that a court ask whether application of the federal statute ${ }^{88}$ to the challenged activity would "invalidate, impair, or supersede" any state law enacted "for the purpose of regulating the business of insurance." 89 This raises at least two major questions of statutory interpretation: ${ }^{30}$ first, which state laws are those enacted for the purpose of regulating the insurance industry, and second, how exacting a scrutiny of the relevant state law is mandated by the "invalidate, impair, or supersede" requirement. The legislative history of the Act provides no guidance on either question.

The Truth in Lending Act and Title VII cases that have reached this second inquiry have, without substantial discussion, consistently looked to the relevant state insurance codes as the source of laws enacted "for the purpose of regulating the business of insurance." ${ }^{\text {91 }}$ Courts have differed more significantly in their understanding of the "invalidate, impair, or supersede" requirement. Although the majority of cases have looked to specific state provisions that would be so affected by application of the federal statute, ${ }^{92}$ some courts also have implied that pervasive regulation of the insurance industry might bar application of federal law even if no state regulation specifically addressed the challenged activity..$^{93}$ This reasoning, apparently derived from judicial interpretations of

ss If the federal statute "specifically relates to the business of insurance," 15 U.S.C. $\S 1012(b)$ (1976), McCarran-Ferguson Act immunity is unavailable. For further discussion of which federal statutes "specifically relate" to the insurance industry, see note 7 supra.

so 15 U.S.C. \& 1012(b) (1976); see note 1 supra.

90 There also is some dispute about whether the state law enacted must be "effective." See Tulane Comment, supra note 2, at 1074-76. See also FTC v. National Cas. Co., 357 U.S. 560, 564-65 (1958); Seasongood v. K \& K Ins. Agency, 548 F.2d 729, 734 (8th Cir. 1977); Ohio AFL-CIO v. Insurance Rating Bd., 451 F.2d 1178, 1180-84 (6th Cir. 1971), cert. denied, 409 U.S. 917 (1972); Manasen v. California Dental Servs., 424 F. Supp. 657, 667-68 (N.D. Cal. 1976), rev'd on other grounds, [1979-1] Trade Cas. 77,069 (9th Cir. 1979).

${ }^{21} 15$ U.S.C. § 1012(b) (1976). See Lowe v. Aarco-American, Inc., 536 F.2d 1160, 1162 (7th Cir. 1976); Spirt v. Teachers Ins. \& Annuity Ass'n, 475 F. Supp. 1298, 1303-04 (S.D.N.Y. 1979), remanded, No. 79-7715 (2d Cir. Feb. 19, 1981); Ben v. General Motors Acceptance Corp., 374 F. Supp. 1199, 1201 (D. Colo. 1974); Gerlach v. Allstate Ins. Co., 338 F. Supp. 642, 650 (S.D. Fla. 1972).

92 E.g., Lowe v. Aarco-American, Inc., 536 F.2d 1160, 1161-62 (7th Cir. 1976); Spirt v. Teachers Ins. \& Annuity Ass'n, 475 F. Supp. 1298, 1303 (S.D.N.Y. 1979), remanded, No. 797715 (2d Cir. Feb. 19, 1981); Gerlach v. Allstate Ins. Co., 338 F. Supp. 642, 650 (S.D. Fla. 1972).

93 E.g., Spirt v. Teachers Ins. \& Annuity Ass'n, 475 F. Supp. 1298, 1303 (S.D.N.Y. 1979), remanded, No. 79-7715 (2d Cir. Feb. 19, 1981); Ben v. General Motors Acceptance Corp., 374 F. Supp. 1199, 1201 (D. Colo. 1974). 
the separate proviso of section 1012(b) that applies in the antitrust context, ${ }^{94}$ can lead to a more pervasive grant of immunity from federal law than is justified by the language of the Act.

This section first addresses the issue of which state laws are enacted for the "purpose of regulating the business of insurance"; it then proceeds to analyze the level of judicial scrutiny that is consistent with the "invalidate, impair, or supersede" requirement. In each instance, the judicial interpretation of the main clause of section 1012(b) is contrasted with the interpretation given to the antitrust proviso that also is contained in that section.

1. State Laws Enacted for the Purpose of Regulating the Business of Insurance. The Supreme Court held in SEC v. National Securities, Inc. ${ }^{95}$ that only those state laws intended to regulate, either directly or indirectly, the insurer-insured relationship trigger McCarran-Ferguson Act immunity. ${ }^{96}$ This statement fails to resolve whether such laws must be part of a state's insurance code or whether state law of general applicability will suffice. For instance, one must determine whether a state premium financing law, not specifically incorporated into a scheme of insurance regulation, would be equivalent to a law enacted for the express purpose of regulating the business of insurance.

One line of cases, involving claims of McCarran-Ferguson Act immunity from the requirements of the Federal Arbitration Act, ${ }^{97}$ has found state arbitration codes of general applicability insufficient to justify the immunity. Both the Second ${ }^{98}$ and Tenth ${ }^{99} \mathrm{Cir}$ cuits reasoned that the state arbitration codes at issue did not regulate the business of insurance; rather, "they are laws of general applicability pertaining to the method of handling contract disputes." 100 In the most recent of the Arbitration Act cases, the Fifth Circuit stated simply that "[a]n examination of the [Georgia] insurance code reveals that it has no provision concerning arbitration clauses." 101 The court did not discuss whether Georgia had any arbitration statute of general applicability that might justify the im-

o4 15 U.S.C. $\S 1012(b)$ (1976); see note 1 supra.

os 393 U.S. 453 (1969).

${ }^{96}$ Id. at 460 .

979 U.S.C. $\S \S 1-14$ (1976). 1969).

${ }^{98}$ Hamilton Life Ins. Co. v. Republic Nat'l Life Ins. Co., 408 F.2d 606, 611 (2d Cir.

${ }^{99}$ Hart v. Orion Ins. Co., 453 F.2d 1358, 1360 (10th Cir. 1971).

100 Id. at 1360 .

101 Miller v. National Security Fidelity Life Ins. Co., 588 F.2d 185, 187 (5th Cir. 1979). 
munity; its citation of the earlier cases decided by the Tenth and Second Circuits ${ }^{102}$ indicates, however, that the existence of such a general statute would not have altered the court's ruling. The Arbitration Act cases suggest that only laws embodied in the state's insurance code are relevant to the McCarran-Ferguson Act inquiry.

The Truth in Lending Act cases that have reached the "invalidate, impair, or supersede" requirement ${ }^{103}$ also have looked to the states' insurance codes as the source of relevant potential conflict. In Gerlach v. Allstate Insurance Co., ${ }^{104}$ the district court relied on Florida's regulation, within its insurance code, of both the fixing of insurance rates and the regulation of insurance premium financing. ${ }^{105}$ Similarly, in Lowe v. Aarco-American, Inc., ${ }^{106}$ the Seventh Circuit found that Illinois regulated both insurance rates and premium financing under its insurance code. ${ }^{107}$ Finally, in Ben $v$. General Motors Acceptance Corp. ${ }^{108}$ the District Court of Colorado concluded that the Truth in Lending Act was inapplicable because "Colorado ha[d] occupied the field of regulating the activities of insurance companies, in a comprehensive manner."108

In Spirt v. Teachers Insurance \& Annuity Association, ${ }^{110}$ the defendants claimed that the McCarran-Ferguson Act exempted them from Title VII's prohibition of sex-segregated mortality tables in the computation of annuity benefits. The court found the comprehensive scheme of insurance regulation in New York to "evidence a legislative belief that discrimination on the basis of sex in the rates and benefits of annuity contracts is not unlawful."111 TIAA's claim that the McCarran-Ferguson Act provided immunity from Title VII therefore was upheld. ${ }^{112}$

102 Id.

${ }^{103}$ Lowe v. Aarco-American, Inc., 536 F.2d 1160 (7th Cir. 1976); Ben v. General Motors Acceptance Corp., 374 F. Supp. 1199 (D. Colo. 1974); Gerlach v. Allstate Ins. Co., 338 F. Supp. 642 (S.D. Fla. 1972).

104338 F. Supp. 642 (S.D. Fla. 1972).

10s Id. at 650. The Gerlach opinion, however, contains a lengthy quotation from California League of Independent Ins. Producers v. Aetna Cas. \& Sur. Co., 175 F. Supp. 857 (N.D. Cal. 1959), where the court had premised its finding of McCarran-Ferguson Act immunity in part on the state's general antitrust laws. Id. at 860 .

${ }^{206} 536$ F.2d 1160 (7th Cir. 1976).

107 Id. at 1161-62.

108374 F. Supp. 1199 (D. Colo. 1974).

100 Id. at 1201 .

110475 F. Supp. 1298 (S.D.N.Y. 1979), remanded, No. 79-7715 (2d Cir. Feb. 19, 1981 ).

111 Id. at 1304.

${ }^{112}$ The Spirt court noted in particular section 209 of the New York Insurance Law, which provides that "no life insurance company doing business in the state shall make or 
In contrast to the interpretation of the main clause of section 1012(b), courts construing the antitrust proviso of that section have looked to a variety of state laws, including some outside the relevant insurance codes. They have referred to state laws prohibiting unfair practices in general, ${ }^{113}$ laws prohibiting illegal restraint of trade, ${ }^{114}$ laws regulating state health care plans, ${ }^{115}$ and state antitrust laws. ${ }^{116}$ What these statutes have in common is an obvious impact on the same activities that are regulated by federal antitrust legislation. If a state clearly has regulated an activity such as sex-based discrimination or interest disclosure requirements through its general statutory scheme, however, and if these laws are in fact applied to the insurance industry, there is no principled reason why they should not satisfy the requirement of laws passed "for the purpose of regulating the business of insurance."117

Such general laws are part of a state's regulation of the insurer-insured relationship, and basing McCarran-Ferguson Act immunity on them does not threaten to extend the immunity beyond the scope envisioned by the Act's framers. In principle, therefore, the antitrust precedent might be more applicable to determining which laws regulate the business of insurance than courts construing the "invalidate, impair, or supersede" requirement have acknowledged. The antitrust proviso analogy that does threaten to expand the immunity beyond reasonable bounds is that interpreting the "to the extent" language of the proviso.118

2. State Laws That Would Be "Invalidated, Impaired, or Superseded" by Application of Federal Law. The principal issue that has arisen in determining whether federal law would "invalidate, impair, or supersede" state law is whether a pervasive scheme

permit any unfair discrimination between individuals of the same class and of equal expectation of life in premiums, rates, dividends or benefits of policies for life insurance or annuities," N.Y. INSURANCE LAW $§ 209$ (McKinney 1966). The court interpreted this provision to proscribe discrimination between individuals of the same class but to permit discrimination among classes or groups presenting different insurance risks. $475 \mathrm{~F}$. Supp. at 1303 . The court also relied on sections $159(1)$ (d) and $160(\mathrm{c})$, which implicitly permit gender to be a factor in setting annuity rates and benefits. Id. at 1304 .

${ }^{113}$ See Commander Leasing Co. v. Transamerican Title Ins. Co., 477 F.2d 77, 83 (10th Cir. 1973).

11 See id.

115 See Manasen v. California Dental Servs., 424 F. Supp. 657, 668 (N.D. Cal. 1976), rev'd on other grounds, [1979-1] Trade Cas. 77,069 (9th Cir. 1979).

${ }^{116}$ See California League of Independent Ins. Producers v. Aetna Cas. \& Sur. Co., 175

F. Supp. 857, 860 (N.D. Cal. 1959).

117 U.S.C. § 1012(b) (1976); see note 1 supra.

118 See note 1 supra. 
of state insurance regulation so occupies the field that no federal law can be deemed applicable to the business of insurance without superseding the state law. ${ }^{119}$ The majority of courts that have construed the main clause have rested their holdings on a careful scrutiny of state law regulating the specific activity in question. ${ }^{120}$ At least two courts, however, have suggested that comprehensive state regulation of the insurance industry does automatically give rise to McCarran-Ferguson Act immunity. ${ }^{121}$ One of the courts maintains that such a reading of the "invalidate, impair, or supersede" requirement is supported by precedent interpreting the antitrust proviso of section $1012(\mathrm{~b}) .{ }^{122}$ Such a broad exemption, however, is not supported by the language of the Act or by the antitrust precedent.

The use of the three terms, "invalidate," "impair," and "supersede," clearly prohibits a court from applying federal law when

110 Part of the difficulty in interpreting this main clause of section 1012(b) is the statute's ambiguity with respect to the relationship between that clause and the antitrust proviso that follows it.

The main clause of section 1012(b), the "invalidate" language dealing with nonantitrust contexts, may be read to grant a substantially broader protection to state law than the proviso of section $1012(\mathrm{~b})$, which refers solely to the antitrust context. State law regulating the insurance industry may be viewed as applicable in the antitrust context only to the extent that it regulates the activity in question, leaving subject to federal law activities that are either unregulated or that could be regulated to a greater degree than state law provides. Acts of Congress in nonantitrust areas, however, would seem to be inapplicable whenever the state had regulated the activity in question, in that any federal law that required compliance above the standard dictated by federal law would "supersede" the state law. See, e.g., Perry v. Fidelity Union Life Ins. Co., 606 F.2d 468, 483 (5th Cir. 1979) (Brown, C.J., dissenting), cert. denied, 100 S. Ct. 2973 (1980).

Alternatively, the main clause and the antitrust proviso may be read as providing essentially the same degree of protection for state law. There is no obvious reason why the "invalidate" language of the main clause of section 1012(b) should not apply in the antitrust context as well, despite the general judicial tendency to regard those two clauses as independent. See Weller, supra note 23, at 602-06. Such an interpretation leaves state law in both the antitrust and nonantitrust areas protected by the full scope of the first clause of section 1012(b), with the second clause serving to reiterate what is implicit in the main clause: that any gap in state regulation in the antitrust area should be filled by existing federal law. See, e.g., Lawyer's Title Co. v. St. Paul Title Ins. Co., 526 F.2d 795, 797 (8th Cir. 1975) (in which the defendant argued that Missouri law would be "invalidated, impaired, or superseded" by application of the Sherman and Clayton Acts).

${ }^{120}$ Lowe v. Aarco-American, Inc., 536 F.2d 1160 (7th Cir. 1976); Spirt v. Teachers Ins. \& Annuity Ass'n, 475 F. Supp. 1298 (S.D.N.Y. 1979), remanded, No. 79-7715 (2d Cir. Feb. 19, 1981); Gerlach v. Allstate Ins. Co., 338 F. Supp. 642 (S.D. Fla. 1972).

${ }^{221}$ Spirt v. Teachers Ins. \& Annuity Ass'n, 475 F. Supp. 1298, 1303 (S.D.N.Y. 1979), remanded, No. 79-7715 (2d Cir. Feb. 19, 1981); Ben v. General Motors Acceptance Corp., 374 F. Supp. 1199, 1201 (D. Colo., 1974).

${ }^{122}$ Spirt v. Teachers Ins. \& Annuity Ass'n, 475 F. Supp. 1298, 1303 n.6 (S.D.N.Y. 1979), remanded, No. 79-7715 (2d Cir. Feb. 19, 1981). 
the statute regulates the specific activity in a different manner or to a different degree than the federal statute. Even if a state has a broad scheme of insurance regulation, however, it may not have enacted legislation pertinent to the specific activity challenged by federal law. In this case, a court that automatically invokes McCarran-Ferguson Act immunity must either be ignoring the "invalidate, impair, or supersede" requirement or be reasoning that the state intended to permit all activity not explicitly addressed in its code. It is this latter interpretation that looks to the antitrust precedent for support. It is important, therefore, to understand the judicial interpretation of the antitrust proviso's limitation that federal antitrust law is applicable only "to the extent that [the insurance] business is not regulated by State Law."123

Courts construing the antitrust proviso frequently have made broad statements to the effect that "a State regulates the business of insurance within the meaning of $\S 1012(b)$ when a State statute generally proscribes... or permits or authorizes certain conduct on the part of the insurance companies."124 Such a broad exemption might be justified in the antitrust-but not the Truth in Lending or Title VII-context on the ground that the McCarranFerguson Act was passed primarily in response to the threat that federal antitrust laws would be applied to the insurance industry. ${ }^{125}$

In fact, however, the courts making such broad statements have conducted a far more particularized inquiry into state law than their broad language would indicate. Some courts have stated, for example, that a general scheme of state regulation of a particular kind of insurance, such as title ${ }^{128}$ or automobile liability ${ }^{127}$ insurance, would be sufficient to invoke McCarran-Ferguson Act immunity. These courts have, however, pointed to specific provisions

12315 U.S.C. $\S 1012(b)$ (1976); see note 1 supra.

124 California League of Independent Ins. Producers v. Aetna Cas. \& Sur. Co., 175 F. Supp. 857, 860 (N.D. Cal. 1959); accord, FTC v. National Cas. Co., 357 U.S. 560, 564 (1958). See also Crawford v. American Title Ins. Co., 518 F.2d 217, 218 (5th Cir. 1975); Commander Leasing Co. v. Transamerica Title Ins. Co., 477 F.2d 77, 84 (10th Cir. 1973); Ohio AFL-CIO v. Insurance Rating Bd., 451 F.2d 1178, 1181 (6th Cir. 1971), cert. denied, 409 U.S. 917 (1972).

${ }^{125}$ See text and notes at notes 8-20 supra.

${ }^{128}$ Lawyers Title Co. v. St. Paul Title Ins. Co., 526 F.2d 795, 797 (8th Cir. 1975); Crawford v. American Title Ins. Co., 518 F.2d 217, 218-19 (5th Cir. 1975); Commander Leasing Co. v. Transamerica Title Ins. Co., 477 F.2d 77, 83 (10th Cir. 1973).

${ }_{127}$ Ohio AFL-CIO v. Insurance Rating Bd., 451 F.2d 1178, 1181 (6th Cir. 1971), cert. denied, 409 U.S. 917 (1972). 
of the state code that at least implicitly regulated the challenged conduct. ${ }^{128}$ They often have buttressed their holdings by reference to state unfair practices statutes, ${ }^{129}$ state antitrust laws, ${ }^{130}$ or, in one case, to a state law regulating health care plans, ${ }^{131}$ that also regulated the challenged conduct. Despite broad language to the contrary, therefore, courts construing the "to the extent" limitation of the proviso have examined the scheme of state regulation for provisions applicable to the activity challenged by federal law. ${ }^{132}$

The reliance of courts construing the main clause of section $1012(\mathrm{~b})$ on the broad language of the antitrust cases rather than on the particularized inquiry that supported those courts' holdings leads to results that are unsupported by the statutory language. For example, in Ben v. General Motors Acceptance Corp. ${ }^{133}$ the court was satisfied that McCarran-Ferguson Act immunity should attach merely because Colorado had regulated insurance companies in a pervasive manner, ${ }^{134}$ without examining that state's insur-

128 Lawyers Title Co. v. St. Paul Title Ins. Co., 526 F.2d 795, 797 (8th Cir. 1975); Ohio AFL-CIO v. Insurance Rating Bd., 451 F.2d 1178, 1182-83 (6th Cir. 1971), cert. denied, 409 U.S. 917 (1972); Celifornia League of Independent Ins. Producers v. Aetna Cas. \& Sur. Co., 175 F. Supp. 857, 860 (N.D. Cal. 1959).

${ }^{129}$ See, e.g., Commander Leasing Co. v. Transamerica Title Ins. Co., 477 F.2d 77, 83 (10th Cir. 1973).

130 See Manasen v. California Dental Servs., 424 F. Supp. 657, 668 (N.D. Cal. 1976), rev'd on other grounds, [1979-1] Trade Cas. 77,069 (9th Cir. 1979); California League of Independent Ins. Producers v. Aetna Cas. \& Sur. Co., 175 F. Supp. 857, 860 (N.D. Cal. 1959).

131 See Manasen v. California Dental Servs., 424 F. Supp. 657, 668 (N.D. Cal. 1976), rev'd on other grounds, [1979-1] Trade Cas. 77,069 (9th Cir. 1979).

132 In United States v. Chicago Title \& Trust Co., 242 F. Supp. 56 (N.D. Ill. 1965), the court found McCarran-Ferguson Act immunity unavailable to defendants who had allegedly violated section 7 of the Clayton Act by engaging in a stock acquisition that had the effect of lessening competition. Id. at 60 . The court found that the state antitrust law did not regulate this activity and stated, "[i]f federal legislation is to be displaced by state regulation, the latter must cover the same ground as the federal legislation." Id. at 57. On its face, this case exemplifies a greater degree of scrutiny than that applied by courts that have rested their holdings in part on the mere existence of state antitrust regulation, see text and note at note 138 supra. Chicago Title is a curious case, however, because the court failed to discuss whether any aspect of the state's insurance code would justify McCarran-Ferguson Act immunity.

The Eighth Circuit, however, in Lawyers Title Co. v. St. Paul Title Ins. Co., 526 F.2d 795 (8th Cir. 1975), was careful to state that its finding of immunity was consistent with Chicago Title. Id. at 797. Earlier in its opinion the Lawyers Title court had noted, 526 F.2d at 797, the "broad scope" of McCarran-Ferguson Act immunity, see text and note at note 128 supra.

1ss 374 F. Supp. 1199 (D. Colo. 1974).

136 Id. at 1201. 
ance code for any specifically applicable regulation. Such an approach threatens to expand the McCarran-Ferguson Act immunity beyond that mandated by the "invalidate, impair, or supersede" clause.

3. Summary. Courts construing the "invalidate, impair, or supersede" clause have looked to the state insurance code as the pertinent source of state regulation, and most have required that the state specifically regulate the challenged activity for McCarran-Ferguson Act immunity to be upheld. Although the courts might, consistent with the statutory language, also look to general state law applicable to insurers, their failure to do so has not affected their holdings because the requisite state regulation was found in the insurance codes. More disturbing is the willingness of some courts to premise McCarran-Ferguson immunity on a pervasive scheme of state regulation without inquiring whether the state code touches the specific activity in question. Such a broad grant of immunity is inconsistent with the language of section 1012(b).

It is by no means clear, therefore, that all courts properly understand the scope of the inquiry that the "invalidate, impair, or supersede" language requires. Even if courts confine their inquiry as the statute requires, however, it is possible that federal legislation will be deemed inapplicable in situations where policy would dictate against recognition of the immunity.

\section{Policy Considerations}

It is a truism that the "starting point in any case involving the construction of a statute is the language of the statute itself."135 The language of the McCarran-Ferguson Act unambiguously grants the insurance industry a broad immunity from federal regulation. ${ }^{138}$ On the other hand, both the Truth in Lending Act and Title VII represent strong congressional statements of public policy. Reconciling the McCarran-Ferguson Act with the federal interests underlying these statutes may be impossible given the present form of these statutes.

The Truth in Lending Act embodies two congressional judgments. The first is that disclosure of credit policies is in the public interest. The second is that one system of minimal disclosure re-

195 St. Paul Fire \& Marine Ins. Co. v. Barry, 438 U.S. 531, 541 (1978).

138 This is true except for the statutes specified in 15 U.S.C. $\S 1014$ (1976), see note 3 supra. 
quirements should be uniformly applied to the fifty states. ${ }^{137} \mathrm{Un}$ like federal antitrust legislation, application of the Truth in Lending Act to the insurance industry does not impinge on business practices intrinsic and essential to insurers. ${ }^{138}$ On its face, the Truth in Lending Act has no greater impact on the insurance industry than on any other nationwide business that utilizes credit. Unless a particular impact is demonstrated, it does not appear essential either that insurers be exempt from disclosure requirements or that such regulation be framed by the legislative body most familiar with the state's insurance code. Because insurers have no principled reason to prefer state to federal regulation of their credit disclosure procedures, the congressional judgment in favor of one uniform standard should prevail. ${ }^{139}$

The case against McCarran-Ferguson immunity from Title VII is even more compelling. ${ }^{140}$ Title VII, and the federal policy against discrimination embodied in the Civil Rights Act of 1964, is a matter of "highest priority."141 Federal antidiscrimination legislation was specifically designed to augment state legislation and establish a supplementary regime of federal standards and supervision. ${ }^{\mathbf{1 4 2}}$ Judicial interpretation of Title VII has determined that discrimination on the basis of sex as to employment benefits and contributions is among the activities that Congress chose to prohibit. ${ }^{14 s}$ Even if one were to argue, therefore, that such discrimination is "intrinsic" to the insurance industry, Title VII represents a congressional judgment that the practice is undesirable. There is no reason why insurers who issue annuity policies should be allowed to engage in sex-based discrimination while others offering annuities are prohibited from doing so. In fact, as an industry with a significant nationwide impact, insurers may even be the subject of

137 The purposes of the uniform federal credit requirements embodied in the Truth in Lending Act were to eliminate consumer confusion and permit easy comparison of commercial alternatives. See Gennuso v. Commercial Bank \& Trust Co., 566 F.2d 437, 441 (3d Cir. 1977); Hickman v. Cliff Peck Chevrolet, Inc., 566 F.2d 44, 46 (8th Cir. 1977).

1ss Rate making and information sharing by insurers were threatened by the application of federal antitrust laws. See Group Life \& Health Ins. Co. v. Royal Drug Co., 440 U.S. 205, 221 (1979).

130 As most insurance companies are active in interstate commerce, the insurance industry, like any other nationwide industry, has an interest in the uniformity of credit regulation among the various states.

140 This case would be equally compelling in matters arising under other antidiscrimination legislation.

141 Alexander v. Gardner-Denver Co., 415 U.S. 36, 47 (1973).

142 See Johnson v. Railway Express Agency, Inc., 421 U.S. 454, 459 (1975).

14 See City of Los Angeles v. Manhart, 435 U.S. 702, 710-12 (1978). 
a particularized federal interest.

Neither the Truth in Lending Act nor Title VII is specifically made applicable to the insurance industry. By construing the phrases "business of insurance" and "invalidate, impair, or supersede" narrowly, ${ }^{144}$ courts can eliminate some potential conflicts between those strong federal policies and the McCarran-Ferguson Act. There is a fine line, however, between narrowly construing those phrases and manipulating the statutory language to achieve a result that is desirable from a particular viewpoint of public policy. ${ }^{145}$ Such manipulation is an undesirable exercise of judicial discretion.

As the McCarran-Ferguson Act currently stands, it has generated conflict in the case law both because of legitimate uncertainty about the scope of immunity envisioned by the Act's framers and because of judicial displeasure with the policy implications of fully recognizing the McCarran-Ferguson Act exemption. It is unlikely that Congress originally considered the full effect that the McCarran-Ferguson Act could have in nonantitrust contexts such as the Truth in Lending Act and Title VII. If this is indeed the case, it is up to Congress to remedy the situation. ${ }^{146}$ The failure of Congress to act can result in judicial interpretations of the McCarran-Ferguson Act that are at odds with the plain language of the statute.

\section{Conclusion}

This comment has shown that the scope of the immunity granted by the McCarran-Ferguson Act in contexts such as the Truth in Lending Act and Title VII has been misunderstood by courts and, at times, impermissibly restricted to achieve policy-ori-

14t See text and notes at notes 34-87 supra.

${ }^{145}$ Decisions such as Perry, Peters, and Cochran avoided confict with the federal law by reading the phrase "business of insurance" too narrowly. See text and notes at notes 47 60, 77-87 supra. It is arguable that the cases construing the Act's immunity from the Federal Arbitration Act similarly misinterpreted the "invalidate, impair, or supersede" requirement by failing to premise immunity on the existence of state arbitration laws, see text and notes at notes $86,97-102$ supra.

Cases such as Dunn and Ben, which relied on a more explicit balancing of the competing statutory interests, see text and notes at notes 76,87 supra, represent a different, but no more desirable, means of manipulating the statute.

${ }^{148}$ See text and note at note 7 supra. If McCarran-Ferguson immunity from Title VII and the Truth in Lending Act is consistent with congressional intent, those two statutes should be amended to make the exemption explicit. Although one would not normally expect Congress to address the status of the insurance industry in a statute of general applicability, the degree of confusion exhibited by recent case law may make such action necessary. 
ented results. The legislative history of the Act and judicial precedents require a broader interpretation of the phrase "business of insurance" than some recent case law has allowed. The majority of those courts that have reached the issue of whether a federal statute "invalidates, impairs, or supersedes" a state law have properly conducted the inquiry required by the Act. Some courts, however, have misapplied precedent from the antitrust context in conducting this inquiry.

It is Congress, and not the courts, therefore, that bears the burden of clarifying the scope of the McCarran-Ferguson Act exemption and harmonizing that statute's grant of immunity with the federal policies expressed in the Truth in Lending Act and Title VII.

Steven Koch 